\title{
Serum Procalcitonin Guided Antibiotic Therapy in Patients with Acute Exacerbation of Chronic Obstructive Pulmonary Disease
}

\author{
Rawshan Arra Khanam¹, Md Ashraful Haque², Mohammad Omar Faruq³
}

\begin{abstract}
:
Chronic obstructive pulmonary disease (COPD) is a preventable and treatable, but progressive disease. Hospital admissions of patients with COPD are frequently due to acute exacerbations of COPD (AECOPD). AECOPD are very common, affecting about 20\% of COPD patients. The bacterial infection plays an important role in the exacerbation of COPD patients. In addition, recent studies using molecular diagnostics indicate that a substantial proportion of AECOPD are associated with viral infection. Accurate methods to differentiate viral and bacterial respiratory infections to allow targeted antibiotic therapy would be beneficial. Acute phase reactants are capable of demonstrating the inflammation; however, they cannot be employed to make a difference between bacterial and nonbacterial causes of the inflammation. Recently, measurement of procalcitonin (PCT) levels appears to be useful in order to minimize this problem.
\end{abstract}

Key words: $A E C O P D, P C T$

\section{Introduction :}

Chronic obstructive pulmonary disease (COPD) is a common preventable and treatable disease. It is characterized by persistent airflow limitation that is usually progressive and associated with an enhanced chronic inflammatory response in the airways and the lung to noxious particles or gases ${ }^{1}$. COPD is a chronic inflammatory disease. It may cause hospital admissions with acute exacerbations in those who do not receive regular treatment or even in those who do as a result of intervening pulmonary infection. Guidelines from the Global Initiative for Chronic Obstructive Pulmonary Disease (GOLD) recommend antibiotics for the treatment of moderate to severe acute exacerbations of chronic obstructive pulmonary disease (AECOPD) $)^{2}$. Several meta-analyses support these recommendations to reduce mortality and treatment failures ${ }^{3}$.

\section{Acute exacerbation of COPD (AECOPD)}

The American Thoracic Society (ATS) and European Respiratory Society (ERS) define an exacerbation as an acute

1. Dr. Rawshan Arra Khanam, MD (Chest diseases), Specialist, Dept. of Medicine, United Hospital Ltd

2. Dr. Md. Ashraful Haque, MBBS, Diploma in Anaesthesia, Specialist, Intensive Care Unit, United Hospital Ltd

3. Dr. Mohammad Omar Faruq, MD, FACP, FACEP, FCCM, FCPS, Professor of Dept of CCM, BIRDEM General Hospital

\section{Corresponding Author:}

Dr Rawshan Arra Khanam

MD (Chest diseases)

Specialist, Dept. of Medicine, United Hospital Ltd.

Plot no 5, Road no 71, Gulshan 2, Dhaka 1212, Bangladesh

Email: rawshan.dr@gmail.com change in a patient's baseline dyspnea, cough, or sputum that is beyond normal variability, and that is sufficient to warrant a change in therapy ${ }^{4}$. AECOPD was considered bacteriologically confirmed in the presence of a positive Gram stain of respiratory samples, a pathogen concentration greater than $10^{5} \mathrm{cfu} / \mathrm{ml}$ in tracheobronchial aspirations, a blood culture revealing a bacterial pathogen in the absence of an extra pulmonary focus, or positive serological tests ${ }^{5}$.

\section{Pathogenesis of exacerbation}

The emerging concept that an increase in airway inflammation from the baseline level characteristic of COPD is central to the pathogenesis of acute exacerbations is supported by several recent studies ${ }^{6,7}$. Measurement of airway inflammation in induced or expectorated sputum, bronchoalveolar lavage or bronchial biopsy has revealed that increased airway inflammation is indeed present in acute exacerbation and resolves with treatment. Both neutrophilic and eosinophilic inflammation has been described, with the former associated with a bacterial etiology and the latter with viral infection.

\section{Microbial pathogens in COPD exacerbation}

The list of potential pathogens in COPD exacerbations includes typical respiratory bacterial pathogens, respiratory viruses and atypical bacteria (Table I). Among the typical bacteria, Nontypeable Haemophilus Influenzae (NTHI) is the most common and its role in COPD is the best understood ${ }^{8}$. A high prevalence of respiratory viruses has been reported in severe AECOPD requiring ventilation. Among the viruses, Rhinovirus and Respiratory Syncytial Virus (RSV) have received considerable attention in recent years ${ }^{9,10}$. 
Bangladesh Crit Care J September 2015; 3 (2): 67-70

Table I: Microbial pathogens in exacerbations of COPD

\begin{tabular}{|c|c|c|c|}
\hline $\begin{array}{l}\text { Pathogen } \\
\text { class }\end{array}$ & $\begin{array}{l}\text { Proportion of } \\
\text { exacerbations }\end{array}$ & Specific species & $\begin{array}{l}\text { Proportion of class } \\
\text { of pathogens }\end{array}$ \\
\hline \multirow[t]{7}{*}{ Bacteria } & $40 \%-50 \%$ & Nontypeable Haemophilus influenza & $30 \%-50 \%$ \\
\hline & & Streptococcus pneumoniae & $15 \%-20 \%$ \\
\hline & & Moraxella catarrhalis & $15 \%-20 \%$ \\
\hline & & Pseudomonas spp. and Enterobacteriaceae & $\begin{array}{l}\text { Isolated in very severe COPD, } \\
\text { concomitant bronchiectasis, } \\
\text { recurrent exacerbations }\end{array}$ \\
\hline & & Haemophilus parainfluenzae & $\begin{array}{l}\text { Isolated frequently, pathogenic } \\
\text { significance undefined }\end{array}$ \\
\hline & & Haemophilus hemolyticus & $\begin{array}{l}\text { Isolated frequently, pathogenic } \\
\text { significance undefined }\end{array}$ \\
\hline & & Staphylococcus aureus & $\begin{array}{l}\text { Isolated infrequently, pathogenic } \\
\text { significance undefined }\end{array}$ \\
\hline \multirow[t]{6}{*}{ Viruses } & $30 \%-40 \%$ & Rhinovirus & $40 \%-50 \%$ \\
\hline & & Parainfluenza & $10 \%-20 \%$ \\
\hline & & Influenza & $10 \%-20 \%$ \\
\hline & & $R S V$ & $10 \%-20 \%$ \\
\hline & & Coronavirus & $10 \%-20 \%$ \\
\hline & & Adenovirus & $5 \%-10 \%$ \\
\hline Atypical & $5 \%-10 \%$ & Chlamydia pneumoniae & $90 \%-95 \%$ \\
\hline bacteria & & Mycoplasma pneumoniae & $5 \%-10 \%$ \\
\hline
\end{tabular}

\section{Differentiating diagnostic tools in AECOPD:}

Classical diagnostic instruments including CRP and leukocyte count do not have sufficient specificity in differentiating between bacterial infections, noninfectious systemic inflammations or viral infections. Recently, serum procalcitonin (PCT) has been used as an infection marker ${ }^{11-14}$. Since the extent and severity of infection gradually increase in bacterial infections, serum PCT levels have also been shown to increase. There is even a specific cut-off value for PCT for the establishment of a bacterial infection ${ }^{15}$.

Procalcitonin (PCT) is a peptide precursor of hormone calcitonin, the later being involved with calcium homeostasis. It is composed of 116 amino acids and is produced by the parafollicular cells ( $\mathrm{C}$ cells) of the thyroid and by the neuroendocrine cells of the lung and the intestine ${ }^{16}$. The level of procalcitonin raises in a response to a proinflammatory stimulus, especially of bacterial origin. Serum PCT levels are detectable as early as 3-4 hours after the invasion, which is much earlier than the increase in the C-reactive protein level or erythrocyte sedimentation rate ${ }^{17,18}$. Available data indicate that PCT levels are not influenced by therapy with glucocorticoids or nonsteroidal anti-inflammatory agents ${ }^{19,20}$. PCT levels do not increase or increase only modestly in patients with infection due to respiratory viruses ${ }^{21}$.
In healthy humans, its normal serum level is $0.1 \mathrm{ng} / \mathrm{ml}$. In serum, procalcitonin has a half-life of 25 to 30 hours. Elevated serum concentrations of PCT was initially detected in patients with sepsis and infection ${ }^{22}$. Hyperprocalcitonemia appears within 2 to $4 \mathrm{hr}$ in patients with infection, often reaches peak values in 8 to $24 \mathrm{~h}$, and then persists as long as the inflammatory process continues. With recovery, PCT levels return to normal ${ }^{23}$. The sensitivity and specificity of PCT in bacterial infections were found to be $92.6 \%$ and $97.5 \%$, respectively ${ }^{24,25}$. In delayed bacterial infections (3-30 days), the sensitivity and specificity reached $100 \%$. Serum PCT level above $0.5 \mathrm{ng} / \mathrm{ml}$ indicates bacterial infections, whereas levels above $2 \mathrm{ng} / \mathrm{ml}$ show sepsis ${ }^{26}$. When the threshold level of PCT indicative of bacterial infection was accepted as 0.5 $\mathrm{ng} / \mathrm{ml}$, the positive and negative predictive values were found to be $100 \%$ and $87 \%$, respectively ${ }^{24,25}$. PCT measurements may also be used to reveal the disease severity ${ }^{27,28}$.

Serum IFN-c levels increase in response to a variety of viral respiratory tract infections ${ }^{29}$. Thus, the absence of an increase in serum PCT levels in patients with viral respiratory tract infection may be due to inhibition of PCT synthesis by IFN-c. In contrast, there are substantive data that human infection with rhinovirus, respiratory syncitial virus (RSV), influenza, adenovirus, and metapneumovirus stimulate a robust cytokine 
response that includes gamma interferon ${ }^{29,30}$. Furthermore, the magnitude of the IFN-c response varies with the type of inciting virus (eg, IFN-c levels are higher in nasopharyngeal secretions obtained from patients with influenza than in RSVinfected patients ${ }^{29}$.

\section{PCT Guidance of antibiotic therapy}

It has always been difficult to decide whether to start antibiotics in patients admitted with COPD exacerbations. Complaints of the patients (increased cough, increased sputum purulence, increased shortness of breath, high fever etc), radiological examinations, and laboratory measurements help clinicians in this respect. PCT measurements, on the other hand, may enable clinicians to distinguish bacterial infections from non-bacterial ones and may make the antibiotic decision easier with an increased confidence. In a recent study, there was a highly statistically significant difference ( $p$ value $<0.001$ ) between AECOPD patients on one side and stable COPD patients and healthy control subjects on the other side regarding the mean values of $\mathrm{PCT}^{31}$ (Table II).

Table II: Comparison between different subject groups regarding PCT levels (ng/ml).

\begin{tabular}{lll}
\hline Groups & PCT Mean $\pm \mathrm{SD}(\mathrm{ng} / \mathrm{ml})$ & $p$ Value \\
\hline 1. AECOPD patients & $1.44 \pm 0.542$ & 1 vs $2<0.01$ \\
2. Stable COPD patients & $0.05 \pm 0.012$ & 1 vs $3<0.01$ \\
3. Control subjects & $0.04 \pm 0.010$ & 2 vs $3>0.05$ \\
\hline
\end{tabular}

In a study by Tasci et al, the mean serum PCT levels in COPD patients with exacerbations were $1.8 \mathrm{ng} / \mathrm{ml}$ and in stable COPD patients was $0.2 \mathrm{ng} / \mathrm{ml}^{32}$. Mohamed and his colleagues found the levels of PCT for patients of group A (bacterial exacerbated COPD) $(2.69 \pm 0.62 \mathrm{ng} / \mathrm{ml})$ were significantly higher than group B (non bacterial exacerbated COPD) (0.07 $\pm 0.02 \mathrm{ng} / \mathrm{ml})$ and control group $(0.05 \pm 0.02 \mathrm{ng} / \mathrm{ml})$ $(p<0.001)^{33}$. Pazarli et al discovered that mean levels of PCT in AECOPD were significantly higher than COPD in stable conditions $^{34}$. In another study by Zhang Y and his colleagues, before treatment, the levels of PCT in the infective COPD group were significantly higher than that in the non-infective group $(p<0.01)$. In the infective group, the levels of PCT after the treatment were much lower than those before treatment $(p<0.05)^{35}$. Tanriverdi et al, found that the mean PCT levels were significantly higher in COPD patients with positive sputum cultures than in patients with negative sputum cultures $^{36}$.

It has been demonstrated antibiotics have a marginal efficacy in the treatment of AECOPD, except among patients with evidence of bacterial infection or severe exacerbation ${ }^{37}$. Less than $50 \%$ of severe AECOPD may be attributed to bacteria, suggesting the potential for excessive antibiotic use in this setting ${ }^{38}$. Therefore, serum procalcitonin level may be considered as a useful tool for predicting bacterial infection, and may prove useful for selecting patients with a lower probability of bacterial infection and limit the inappropriate use of antibiotics, specifically in the ICU setting where antibiotic use and the emergence of antimicrobial resistance are highly prevalent ${ }^{39}$. This suggests that COPD exacerbations with a high PCT value may be a result of a bacterial infection even if a bacterial growth is absent, and antibiotic use is mandatory in these patients. In this context, we speculate that antibiotic use in the subgroup of severe AECOPD with lower PCT $(<0.1 \mu \mathrm{g} / \mathrm{L})$, could be reduced also.

Despite many studies demonstrating marginal efficacy for antibiotic therapy in COPD, $85 \%$ of patients with COPD exacerbations are treated with antibiotics ${ }^{40}$. In addition, despite the fact that lower respiratory tract infections (LRTI) are frequently due to viral infections, up to $75 \%$ of these patients seen in general medical practices are treated with antibiotics ${ }^{41}$. Current guidelines recommend antibiotic therapy for most patients with acute exacerbation of COPD of 3 to 7 days $^{42}$. Thus, it is widely agreed that antibiotics are overprescribed. This misuse of antibiotics can be harmful in two ways: patient-specific side effects from treatment and population- based adverse events related to development of bacterial resistance.

\section{Conclusion :}

Nevertheless, we can conclude that PCT-guided antibiotic therapy in patients with AECOPD is likely to reduce antibiotic use and exposure without a detrimental effect on patient safety.

\section{Referrences:}

1. Global strategy for the diagnosis, management and prevention of chronic obstructive pulmonary disease 2014.

2. Pauwels RA, Buist AS, Calverley PM, Jenkins CR, Hurd SS. GOLD Scientific Committee. Global strategy for the diagnosis, management, and prevention of chronic obstructive pulmonary disease. NHLBI/ WHO global initiative for chronic obstructive lung disease (GOLD) workshop summary. Am J Respir Crit Care Med. 2001; 163(5):1256-76.

3. Ram FS, Rodriguez-Roisin R, Granados-Navarrete A, Garcia-Aymerich J, Barnes NC. Antibiotics for exacerbations of chronic obstructive pulmonary disease. Cochrane Database Syst Rev 2006.

4. Qaseem A, Wilt TJ, Weinberger SE, Hanania NA, Criner G. American College of Physicians; American College of Chest Physicians; American Thoracic Society; European Respiratory Society. Diagnosis and management of stable chronic obstructive pulmonary disease: a clinical practice guideline update from the American College of Physicians, American College of Chest Physicians, American Thoracic Society, and European Respiratory Society. Ann Intern Med 2011; 155(3):179-91.

5. Soler N, Torres A, Ewig S, Gonzalez J, Celis R. Bronchial microbial patterns in severe exacerbations of chronic obstructive pulmonary disease (COPD) requiring mechanical ventilation. Am J Respir Crit Care Med 1998; 157: 1498-1505.

6. Sethi S. New developments in the pathogenesis of acute exacerbations of chronic obstructive pulmonary disease. Curr Opin Infect Dis 2004b; 17: 113-19.

7. White AJ, Gompertz S. Chronic obstructive pulmonary disease. 6: The etiology of exacerbations of chronic obstructive pulmonary disease. Thorax 2003; 58:73-80

8. Eldika N, Sethi S. Role of nontypeable Haemophilus influenzae in exacerbations and progression of chronic obstructive pulmonary disease. Curr Opin Pulm Med 2006; 12: 118-24. 
9. Seemungal T, Harper-Owen R. Respiratory viruses symptoms, and inflammatory markers in acute exacerbations and stable chronic obstructive pulmonary disease. Am J Respir Crit Care Med 2001; 164:1618-23.

10. Falsey AR, Hennessey PA, et al. Respiratory syncytial virus infection in elderly and high-risk adults. N Engl J Med 2005; 352:1749-59.

11. Zarka V, Valat C, Lemaria E, Boissinot E, Carre P. Procalcitonin and respiratory tract infections. Rev Pneumol Clin 1999; 55(6): $365-9$.

12. Ugarte H, Silva E, Mercan D, De Mendonça A, Vincent JL. Procalcitonin used as a marker of infections in the intensive care unit. Crit Care Med 1999; 27(3): 498-504.

13. VanLeeuwen HJ, Voorbij HA. Procalcitonin concentrations in the diagnosis of acute inflammatory reactions. Ned Tijdschr Geneeskd 2002; 146(2): 55-9.

14. Korppi M, Remes S, Heiskanen-Kosma T. Serum procalcitonin concentrations in bacterial pneumonia in children: a negative result in primary healthcare settings. Peditr Pulmonol 2003;35(1): 56-61.

15. Brunkhorst FM, Al-Nawas B, Krummenauer F. Procalcitonin $\mathrm{C}$-reactive protein and APACHE II score for risk evaluation in patients with severe pneumonia. Clin Microbiol Infect 2002; 8(2): 93-100.

16. Christ-Crain M, Muller B. Biomarkers in respiratory tract infections: diagnostic guides to antibiotic prescription, prognostic markers and mediators Eur Respir J 2007; 30:556-73.

17. Becker KL, Snider R, Nylen ES. Procalcitonin in sepsis and systemic inflammation: a harmful biomarker and a therapeutic target. Br J Pharmacol 2010; 159 (2): 253-64.

18. Gilbert N. Procalcitonin as a biomarker in respiratory tract infection Clin Infect Dis, 52 (Suppl. 4) (2011): S346-S350.

19. Perren A, Cerutti B, Lepori M. Influence of steroids on procalcitonin and C-reactive protein in patients with COPD and community-acquired pneumonia Infection. 2008; 36: 163-66.

20. Preas HL, Nylen ES, Snider RH. Effects of anti-inflammatory agents on serum levels of calcitonin precursors during experimental endotoxemia. J Infect Dis 2001; 184: 373-6.

21. Walsh E, Falsey A, Nylen E. Serum biomarker measurements in adults with viral infections, Abstract D-2258, ICAAC 2008.

22. Assicot, M, et al. 1993. High serum procalcitonin concentration in patients with sepsis and infection. Lancet 341: 515-18.

23. Becker, K L, Snider R, and Nylen ES. 2008. Procalcitonin assay in systemic inflammation, infection, and sepsis: clinical utility and limitations. Crit Care Med 36:941-952.

24. Rey C, Los Arcos M, Concha A, Medina A. Procalcitonin and CRP as markers of systemic inflammatory response syndrome severity in critical ill children. Intensive Care Med 2007; 33: 477-84.

25. Gendrel D, Raymond J, Assicot M, Moulin F. Measurement of procalcitonin levels in children with bacterial or viral meningitis. Clin Infect Dis 1997; 24: 1240-2.

26. Carrol ED, Thomson APJ, Hart CA. Procalcitonin as a marker of sepsis. Int J Antimicrob Agents 2002; 20: 1-9.

27. Jensen JU, Heslet L, Jensen TH. Procalcitonin increase in early identification of critically ill patients at high risk of mortality. Crit Care Med 2006; 34(10):2596-602.
28. Dorizzi RM, Polati E, Sette P, Ferrari A .Procalcitonin in the diagnosis of inflammation in intensive care units. Clin Biochem 2006; 39: 1138-43.

29. Melendi GA, Laham FR, Monsalvo C. Cytokine profiles in the respiratory tract during primary infection with human meta-pneumovirus, respiratory syncytial virus or influenza virus in infants. Pediatrics 2007; 120:410-5.

30. Sato M, Hosoya M, Wright PF. Differences in serum cytokine levels between influenza virus $\mathrm{A}$ and $\mathrm{B}$ infections in children. Cytokine 2009; 47:65-8.

31. Halim AAE, Sayed M. The value of serum procalcitonin among exacerbated COPD patients. Egyptian Journal of Chest Diseases and Tuberculosis. (Available online 11 June 2015).

32. Tasci C, Balkan A, Karadurmus N, Inal S, Kilic S. The importance of serum procalcitonin levels in patients with COPD exacerbations Turk J Med Sci 2008;38 (2): 139-44.

33. Mohamed KH, Abderabo MM, Ramadan ES. Procalcitonin as a diagnostic marker in acute exacerbation of COPD. Egypt J Chest Dis Tuberc 2012(61): 301-05.

34. Pazarli AC, Koseoglu HI, Doruk S, Berktas S. Procalcitonin: is it a predictor of noninvasive positive pressure ventilation necessity in acute chronic obstructive pulmonary disease exacerbation? J. Res. Med. Sci. 2012; 17(11): 1047-51.

35. Zhou ZL. Diagnostic value of C-reactive protein and procalcitonin for bacterial infection in acute exacerbations of chronic obstructive pulmonary disease. Zhong Nan Da Xue Xue Bao Yi Xue Ban 2014; 39 (9): 939-43.

36. Tanrıverdi H, Ornek T, Erboy F. Comparison of diagnostic values of procalcitonin, C-reactive protein and blood neutrophil/lymphocyte ratio levels in predicting bacterial infection in hospitalized patients with acute exacerbations of COPD Wien. Klin Wochenschr (2015) (Epub ahead of print).

37. Puhan MA, Vollenweider D, Latshang T. Exacerbations of chronic obstructive pulmonary disease:when are antibiotics indicated? A systematic review. Respir Res 2007, 4(8): 30.

38. Martinez FJ, Curtis JL. Procalcitonin-guided antibiotic therapy in COPD exacerbations: closer but not quite there. Chest 2007, 131:1-2.

39. Singh N, Rogers P, Atwood CW. Short-course empiric antibiotic therapy for patients with pulmonary infiltrates in the intensive care unit. A proposed solution for indiscriminate antibiotic prescription. Am J Respir Crit Care Med 2000;162: 505-11.

40. Lindenauer P. K, et al. Quality of care for patients hospitalized for acute exacerbations of chronic obstructive pulmonary disease. Ann Intern Med 2006; 144:894-903.

41. Macfarlane J, Lewis SA, Macfarlane R, and Holmes W. Contemporary use of antibiotics in 1089 adults presenting with acute lower respiratory tract illness in general practice in the UK implication for developing management guidelines. Respir Med 1997; 91: 427-34.

42. Mandell L A, et al. Infectious Diseases Society of America/American Thoracic Society consensus guideline on the management of community- acquired pneumonia in adults. Clin Infect Dis 2007 44: S27-S72. 